\title{
Involvement of 5-lipoxygenase in programmed cell death of cancer cells
}

\author{
Mauro Maccarrone ${ }^{1,2}$, Maria Valeria Catani ${ }^{2}$, \\ Alessandro Finazzi Agrò ${ }^{1}$ and Gerry Melino ${ }^{2,3}$ \\ 1 Department of Experimental Medicine and Biochemical Sciences, University of \\ Rome 'Tor Vergata' 00133 Rome, Italy \\ 2 IDI-IRCCS Biochemistry Laboratory, University of Rome 'Tor Vergata', 00133 \\ Rome, Italy \\ 3 Department of Biology, University of L'Aquila, 67100 L'Aquila, Italy \\ ${ }^{4}$ corresponding author: Gerry Melino, IDI-IRCCS Biochemistry Laboratory, \\ Department of Experimental Medicine and Biochemical Sciences, Room F153/ \\ D27, University of Rome Tor Vergata, via Tor Vergata 135, 00133 Rome, Italy. \\ tel: +39 6 72596453; fax: +39 6 20427290; e-mail melino@tovvx1.ccd. \\ utovrm.it.
}

Received 13.9.96; revised 13.1.97; accepted 17.2.97

Edited by B.A. Osborne

\begin{abstract}
We investigated the involvement of 5-lipoxygenase activity in the early phases of programmed cell death (PCD) induced by $\mathrm{H}_{2} \mathrm{O}_{2}$ or retinoids in different human tumour cells (erythroleukaemia, neuroblastoma, melanoma). Apoptotic cells showed enhanced 5-lipoxygenase activity which was paralleled by decreased superoxide dismutase activity and increased light emission. Ultraweak luminescence, mainly due to membrane lipid peroxidation by lipoxygenase activation, increased in all cell lines tested within 10-15 min after induction of $P C D$, in a concentration and time-dependent manner. At the same time, we observed a significant increase in the intracellular steady state level of the 5-lipoxygenase metabolite leukotriene $B_{4}$. Furthermore, 5-lipoxygenase metabolite 5-hydroxyeicosatetraenoic acid was able to induce PCD in all cell lines tested. Conversely, the general lipoxygenase inhibitor nordihydroguaiaretic acid and the selective 5-lipoxygenase inhibitor caffeic acid protected the different tumour cells from $\mathrm{H}_{2} \mathrm{O}_{2}$-induced PCD to a similar extent. These results show the activation of the 5lipoxygenase pathway in PCD of three different cancer cell lines.
\end{abstract}

Keywords: cell death; erythroleukaemia; leukotriene $\mathrm{B}_{4}$; lipoxygenase; melanoma; neuroblastoma

Abbreviations: 5 - $\mathrm{H}(\mathrm{P}) \mathrm{ETE}, \quad$ 5-hydro(pero)xyeicosa6,8,11,14-tetraenoic acid; $\mathrm{LTB}_{4}$, leukotriene $\mathrm{B}_{4}$; NDGA, nordihydroguaiaretic acid; PBS, phosphate-buffered saline; PCD, programmed cell death; RA, all-trans retinoic acid; ROS, reactive oxygen species; Tunel, TdT-mediated dUTPbiotin nick end labelling.

\section{Introduction}

The mechanisms responsible for the morphological and biochemical hallmarks of programmed cell death (PCD) are not yet fully understood (Raff, 1992; Hale et al, 1996). Reactive oxygen species (ROS) and lipid peroxides have been considered crucial elements in PCD (Hockenbery et al, 1993; Kane et al, 1993); for example, the apoptosis of thymocytes involves oxygen metabolites (Torres-Roca et al, 1995; Wolfe et al, 1994). A possible mechanism has been suggested to link the redox regulation to the expression of transcription factors such as NF-kB and Fos-Jun (Abate et al, 1990; Meyer et al, 1993) explaining the connection between oxidative stress and PCD. Despite evidence for the involvement of ROS in PCD, oxygen radicals have not been directly identified in apoptotic cells, furthermore other data seem contradictory. The anti-apoptotic effect of $\mathrm{Bcl}-2$ has been related to its ability to decrease the net cellular generation of ROS and lipid peroxides (Hockenbery et al, 1993; Kane et al, 1993); however, Bcl-2 is also able to protect cells from apoptotic death induced by several unrelated stimuli, such as ceramide (Martin et al, 1995), and Bcl-2 $2 \mathrm{C}$ has been shown to have pro-oxidant activity in murine B-cells (Steinman, 1995). On the other hand, anoxia is known to induce endonuclease activity (Stoler et al, 1992), typical of $P C D$, indicating that ROS are not required for PCD, while Bcl2 still protects from death in these conditions (Jacobson and Raff, 1995; Shimizu et al, 1995). Thus, Bcl-2 may act by a mechanism different from the regulation of the oxidative balance, such as the $\mathrm{Bcl}-2 / \mathrm{Bax}$ rheostatic mechanism involving several members of the Bcl-2 family (Boise et al, 1993; Chittenden et al, 1995; Farrow et al, 1995; Klefer et al, 1995; Oltvai et al, 1993; Takayama et al, 1995; Yang et al, 1995). Despite some controversy, intracellular oxidants (ROS) seem related to the apoptotic process. Together with mitochondrial electron transport, arachidonic acid metabolites are the major generator of ROS. Consequently, the metabolites of arachidonic acid might contribute to controlling the fate of the cell, via the production of ROS, the damage of important intracellular components and the expression of other genes, including those implicated in PCD. Recently, some evidence has shown the involvement of arachidonic acid metabolites in PCD (Hebert et al, 1996; Tang et al, 1996). Here, we would like to contribute by evaluating the involvement of 5-lipoxygenase in cell death.

Although the nucleus plays a central role in PCD, cellular membranes are the primary site of action of several PCD inducers and lipid messengers act as regulators of apoptosis (Bissonnette et al, 1995; McGahon et al, 1995). 5-Lipoxygenase (EC 1.13.11.34) plays a critical role in lipidmediated signal transduction (Los et al, 1995) and its metabolites were recently found to be active in the nucleus of human cells (Jakobsson et al, 1995). Mammalian lipoxygenases are also able to directly oxygenate cell 
membranes, introducing peroxides in the lipid bilayers (Kühn et al, 1990; Schnurr et al, 1996). In this study, we used different human cancer cells to demonstrate the involvement of 5-lipoxygenase in PCD.

\section{Results}

\section{Modulation of oxygen-related enzyme activities in $\mathrm{H}_{2} \mathrm{O}_{2}$-induced apoptosis}

PCD was induced by $\mathrm{H}_{2} \mathrm{O}_{2}$-mediated oxidative stress, as described by Hockenbery et al (1993) and in our cellular models by De Laurenzi et al (1995). In order to use different systems, the cell lines were selected among classic unrelated models to study apoptosis, currently used by several laboratories. The induction of apoptosis, at least in some models, is accompanied by a downregulation of the expression of mRNA of antioxidant enzymes, such as catalase, superoxide dismutase, DT-diaphorase and thioredoxin (Briehl et al, 1995). We repeated these measurements in our cell systems extending the observation to 5lipoxygenase. After the $\mathrm{H}_{2} \mathrm{O}_{2}$ pulse, all cell lines showed increased 5-lipoxygenase activity and decreased superoxide dismutase activity (Table 1). The activation of 5-lipoxygenase was evident at a very early stage of PCD induction, although at this point there was still no sign of apoptotic body formation (Table 1). Catalase activity sharply increased after exposure to hydrogen peroxide and then decreased towards the control values (Table 1). These data are at variance with the recently reported downregulation of catalase activity in dexamethasone-induced PCD in mouse lymphoid cells (Baker et al, 1996).
Neuroblastoma SK-N-BE(2) cells undergo PCD when treated with RA for 3 to 5 days (Melino et al, 1994; Piacentini et al, 1992, 1993). Table 2 shows that retinoids increased PCD in parallel to a significant enhancement of 5-lipoxygenase activity. In previous experiments, we showed that RA treatment of SK-N-BE(2) cells reduces superoxide dismutase activity and increases catalase activity to $50 \%$ and $120 \%$ of the control values, respectively (Steinkühler et al, 1988). Therefore, modulation of antioxidant enzymes by $\mathrm{RA}$ resembles that observed upon $\mathrm{H}_{2} \mathrm{O}_{2}$ pulse.

Table 2 Changes of 5-lipoxygenase activity and luminescence in RA-induced apoptosis

\begin{tabular}{lccc}
\hline Sample & $\begin{array}{c}\text { Apoptotic bodies } \\
\text { (\%) }\end{array}$ & $\begin{array}{c}\text { 5-lipoxygenase } \\
\text { activity }\end{array}$ & $\begin{array}{c}\text { Luminescence } \\
\text { (\%) }\end{array}$ \\
\hline control & $4.6 \pm 0.4$ & $\begin{array}{c}0.18 \pm 0.01 \\
(100 \%)\end{array}$ & 100 \\
RA (3 days) & $7.3 \pm 0.6$ & $\begin{array}{c}0.28 \pm 0.02 \\
(155 \%)\end{array}$ & $152 \pm 15$ \\
RA (5 days) & $12.6 \pm 1.0$ & $0.36 \pm 0.04$ & $178 \pm 20$ \\
& & $(200 \%)$ & \\
\hline
\end{tabular}

Effects of $1 \mu \mathrm{M}$ retinoic acid (RA) on apoptotic body formation, 5-lipoxygenase activity and luminescence of SK-N-BE (2) cells. 5-lipoxygenase activity is expressed as both nmol 5-HPETE formed $x \min ^{-1} x \mathrm{mg}^{-1}$ protein $^{-1}( \pm$ S.D.) and percentage of the control (in brackets). Formation of apoptotic bodies was measured by cytofluorimetry and Hoechst staining. Data are the mean of three independent experiments, each one performed in duplicate, with $p$ values $<0.01$ vs. control.

Table 1 Activities of oxygen-related enzymes in $\mathrm{H}_{2} \mathrm{O}_{2}$-induced apoptosis

\begin{tabular}{|c|c|c|c|c|}
\hline Sample & $\begin{array}{c}\text { Apoptotic } \\
\text { bodies } \\
(\%)\end{array}$ & $\begin{array}{c}\text { 5-lipoxygenase } \\
\text { activity }\end{array}$ & $\begin{array}{c}\text { Superoxide } \\
\text { dismutase } \\
\text { activity }\end{array}$ & $\begin{array}{l}\text { Catalase } \\
\text { activity }\end{array}$ \\
\hline K562 control & $2.5 \pm 0.3$ & $\begin{array}{c}0.36 \pm 0.04 \\
(100 \%)\end{array}$ & $\begin{array}{c}9.50 \pm 1.00 \\
(100 \%)\end{array}$ & $\begin{array}{c}40.84 \pm 4.10 \\
(100 \%)\end{array}$ \\
\hline $\mathrm{K} 562+\mathrm{H}_{2} \mathrm{O}_{2}(15 \mathrm{~min})$ & $3.3 \pm 0.3^{a}$ & $\begin{array}{c}0.61 \pm 0.06 \\
(170 \%)\end{array}$ & $\begin{array}{c}7.10 \pm 0.75^{\mathrm{b}} \\
(75 \%)\end{array}$ & $\begin{array}{c}72.21 \pm 7.25 \\
(177 \%)\end{array}$ \\
\hline $\mathrm{K} 562+\mathrm{H}_{2} \mathrm{O}_{2}(24 \mathrm{~h})$ & $39.7 \pm 3.0$ & $\begin{array}{c}0.72 \pm 0.07 \\
(200 \%)\end{array}$ & $\begin{array}{c}4.75 \pm 0.45 \\
(50 \%)\end{array}$ & $\begin{array}{c}34.42 \pm 3.45^{\mathrm{b}} \\
(84 \%)\end{array}$ \\
\hline SK-N-BE (2) control & $4.6 \pm 0.4$ & $\begin{array}{l}0.18 \pm 0.01 \\
(100 \%)\end{array}$ & $\begin{array}{c}2.20 \pm 0.20 \\
(100 \%)\end{array}$ & $\begin{array}{c}19.24 \pm 1.95 \\
(100 \%)\end{array}$ \\
\hline SK-N-BE (2)+ $\mathrm{H}_{2} \mathrm{O}_{2}(15 \mathrm{~min})$ & $8.0 \pm 0.7$ & $\begin{array}{l}0.34 \pm 0.03 \\
(189 \%)\end{array}$ & $\begin{array}{c}1.15 \pm 0.10 \\
(52 \%)\end{array}$ & $\begin{array}{c}27.36 \pm 2.75 \\
(142 \%)\end{array}$ \\
\hline SK-N-BE (2) $+\mathrm{H}_{2} \mathrm{O}_{2}(24 \mathrm{~h})$ & $13.8 \pm 1.2$ & $\begin{array}{c}0.38 \pm 0.04 \\
(211 \%)\end{array}$ & $\begin{array}{c}0.50 \pm 0.05 \\
(23 \%)\end{array}$ & $\begin{array}{c}23.58 \pm 2.35 \\
(122 \%)^{b}\end{array}$ \\
\hline B-mel control & $1.1 \pm 0.2$ & $\begin{array}{l}0.18 \pm 0.01 \\
(100 \%)\end{array}$ & $\begin{array}{c}15.30 \pm 1.50 \\
(100 \%)\end{array}$ & $\begin{array}{c}6.09 \pm 0.61 \\
(100 \%)\end{array}$ \\
\hline $\mathrm{B}-\mathrm{mel}+\mathrm{H}_{2} \mathrm{O}_{2}(5 \mathrm{~min})$ & $0.9 \pm 0.2^{a}$ & $\begin{array}{l}0.32 \pm 0.03 \\
(178 \%)\end{array}$ & $\begin{array}{c}12.10 \pm 1.25^{\mathrm{b}} \\
(79 \%)\end{array}$ & $\begin{array}{c}10.79 \pm 1.10 \\
(177 \%)\end{array}$ \\
\hline $\mathrm{B}-\mathrm{mel}+\mathrm{H}_{2} \mathrm{O}_{2}(24 \mathrm{~h})$ & $14.1 \pm 1.3$ & $\begin{array}{c}0.38 \pm 0.04 \\
(211 \%)\end{array}$ & $\begin{array}{c}3.20 \pm 0.30 \\
(21 \%)\end{array}$ & $\begin{array}{c}7.66 \pm 0.75^{b} \\
(126 \%)\end{array}$ \\
\hline
\end{tabular}

Effects of hydrogen peroxide on the activity of 5-lipoxygenase ( $\mathrm{nmol} 5$-HPETE formed $x \mathrm{~min}^{-1} x \mathrm{mg}_{\text {protein }}^{-1}$ ), superoxide dismutase (units $x$ mg protein ${ }^{-1}$ ) and catalase $\left(\mu \mathrm{mol} \mathrm{H}_{2} \mathrm{O}_{2}\right.$ degraded $x$ min $^{-1} x$ mg protein ${ }^{-1}$ ) of K562, SK-N-BE (2) and B-mel cells. Formation of apoptotic bodies was measured by cytofluorimetry (reported in the Table) and Hoechst staining (not shown). $10 \mathrm{mM} \mathrm{H} \mathrm{O}_{2}$ was used for $\mathrm{K} 562$ and SK-N-BE (2) cell treatment, but 5 mM only for B-mel cells. These conditions also yielded the highest luminescence, as shown in Figure 1. The Table reports the absolute values ( + S.D.) and the percentage with respect to the controls (in brackets). Data are the mean of three independent experiments, each one performed in duplicate, with $p$ values $<0.01$ vs. control, if not stated otherwise. ${ }^{a}$ Denotes $p>0.05$ vs. control; ${ }^{b}$ denotes $p<0.05$ vs. control. 


\section{Increase of lipid peroxidation in cells treated with $\mathrm{H}_{2} \mathrm{O}_{2}$}

We have measured cellular luminescence in order to evaluate the amount of lipid peroxides formed in the lipid bilayers of cells in response to hydrogen peroxide (Maccarrone et al, 1995a,b; Nakano et al, 1994). Treatment with $\mathrm{H}_{2} \mathrm{O}_{2}$ increased the luminescence in all the cell types studied (Figure 1). Light emission after the addition of $\mathrm{H}_{2} \mathrm{O}_{2}$ was concentration- and time-dependent, but each cell type showed a maximum response at a typical dose and time (Figure 1B and C). Higher concentrations of, or longer incubation with hydrogen peroxide consistently resulted in a decrease of luminescence. The experimental conditions which yielded the largest increases of luminescence in each cell type yielded a significant increase in 5-lipoxygenase activity as well (Table 1). Table 1 also shows that K562, SK-N-BE(2) and B-mel cells exposed to the respective optimal hydrogen peroxide stimulus and then cultured for $24 \mathrm{~h}$ had a significant increase in apoptotic body formation, as evaluated by flow cytometry and Hoechst staining. This increase in apoptotic bodies was significantly less pronounced in cells pulsed with other lessthan-optimal amounts of hydrogen peroxide and then cultured for $24 \mathrm{~h}$ (data not shown).

To better correlate the activation of 5-lipoxygenase with programmed cell death, we separated by gradient centrifugation live cells from dead cells $24 \mathrm{~h}$ after treatment with $10 \mathrm{mM} \mathrm{H} \mathrm{H}_{2} \mathrm{O}_{2}$. Dying $\mathrm{K} 562$ cells (higher density; $70.4 \pm 6.0 \%$ apoptotic event by flow cytometry) show an activity of 5-lipoxygenase of $1.18 \pm 0.10 \mathrm{nmol} 5$ HPETE $\times \min ^{-1} \times \mathrm{mg}_{\text {protein }}{ }^{-1}$; while K562 cells before separation $(39.7 \pm 2.8 \%$ apoptotic event by flow cytometry) show an activity of 5-lipoxygenase of $0.72 \pm 0.07 \mathrm{nmol} 5$ HPETE $\times \min ^{-1} \times \mathrm{mg}$ protein ${ }^{-1}$. This increase in both apoptotic events (177\%) and 5-lipoxygenase activity $(164 \%)$ in dying cells over the whole cell population, indicates that the activation of 5-lipoxygenase at $24 \mathrm{~h}$ does indeed correlate with the death pathway and is not related with other phenomena occurring in the fraction of live cells.

In order to verify whether the activation of 5-lipoxygenase and luminescence also occurred with a different inducer of PCD, we treated neuroblastoma cells with retinoic acid for 3 or 5 days, a model well-characterised in our laboratory (Melino et al, 1994; Piacentini et al, 1992, 1993). Treatment with retinoids significantly increased light emission from neuroblastoma cells (Table 2), although longer incubation times were needed due to the slower induction of PCD in this model (Melino et al, 1994; Piacentini et al, 1992, 1993).

\section{Involvement of 5-lipoxygenase in PCD}

The activation of 5-lipoxygenase in cells undergoing PCD should result in the overproduction of its intracellular metabolites, such as $\mathrm{LTB}_{4}$ (Jakobsson et al, 1995). K562, SK-N-BE(2) and B-mel cells indeed show a significant increase (in the $\mathrm{nM}$ range) in $\mathrm{LTB}_{4}$ levels within the cell (2.9- to 15-fold, depending on the cell line), when pulsed with hydrogen peroxide (Figure 2A). The increase in $\mathrm{LTB}_{4}$ was as rapid as the activation of 5-lipoxygenase, though $\mathrm{LTB}_{4}$ then declined towards the basal level, whereas 5-lipoxygenase activity remained high (compare Figure $2 \mathrm{~A}$ and Table 1 ). This finding might suggest a rapid $\mathrm{LTB}_{4}$ turnover and might be explained by the fact that leukotrienes are not the sole products of 5-lipoxygenase, which might also act in membrane oxygenation (Kühn et al, 1990; Schnurr et al,
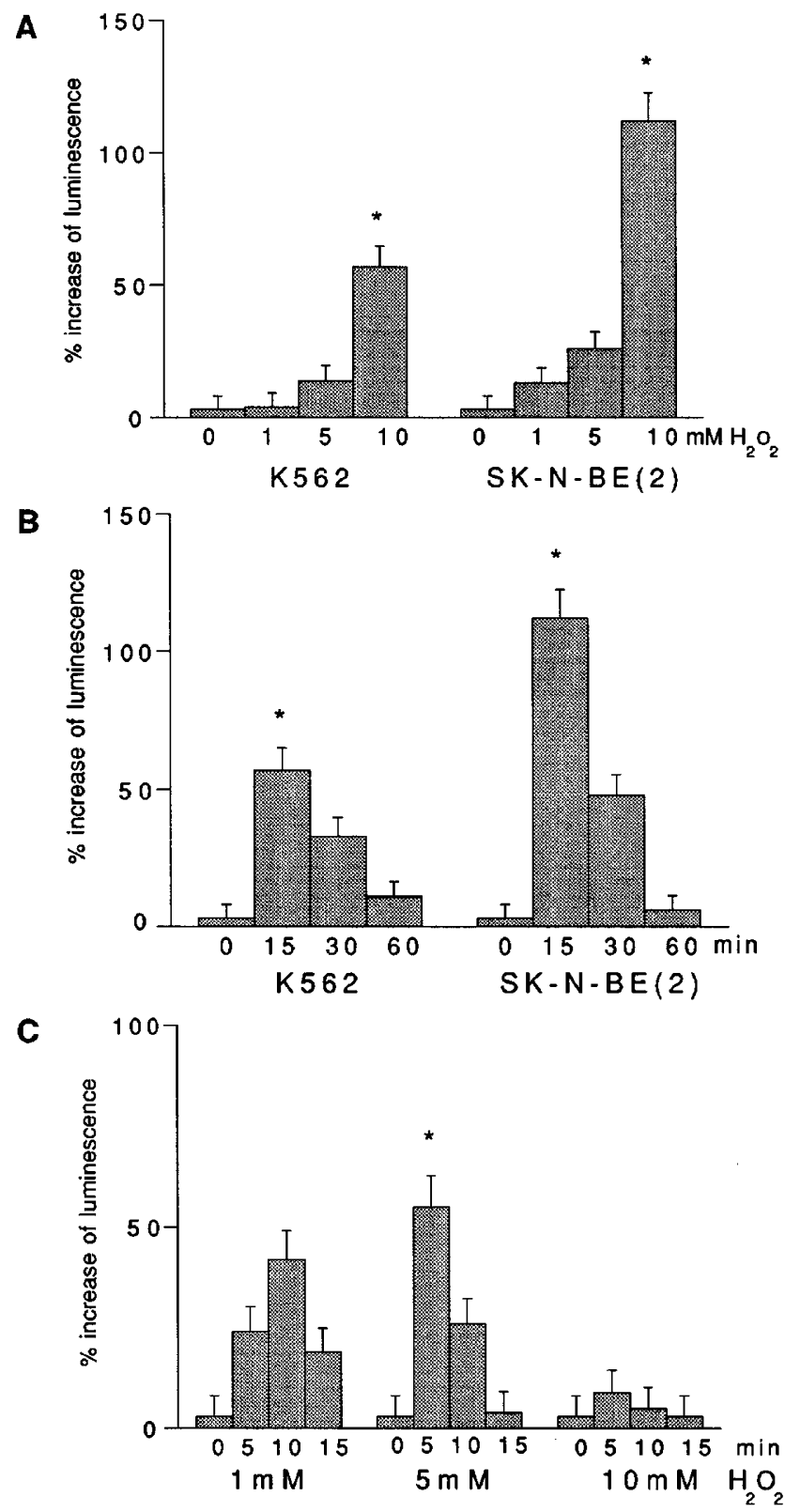

Figure 1 Effect of $\mathrm{H}_{2} \mathrm{O}_{2}$ on the ultraweak luminescence of K562, SK-N-BE(2) and B-mel cells. (A) shows cells incubated for $15 \mathrm{~min}$ in the suitable culture media containing the indicated concentrations of hydrogen peroxide. The asterisks indicate the concentrations that were chosen for time-course experiments. (B) shows the effect of the incubation time on luminescence of $\mathrm{K} 562$ and SK-N-BE(2) cells, incubated with $10 \mathrm{mM} \mathrm{H}_{2} \mathrm{O}_{2}$. (C) shows the effects of hydrogen peroxide concentration and incubation time on luminescence of $\mathrm{B}$ mel cells. The asterisks in $(\mathbf{B}-\mathbf{C})$ indicate the experimental conditions corresponding to the largest increases in 5-lipoxygenase activation. 
A

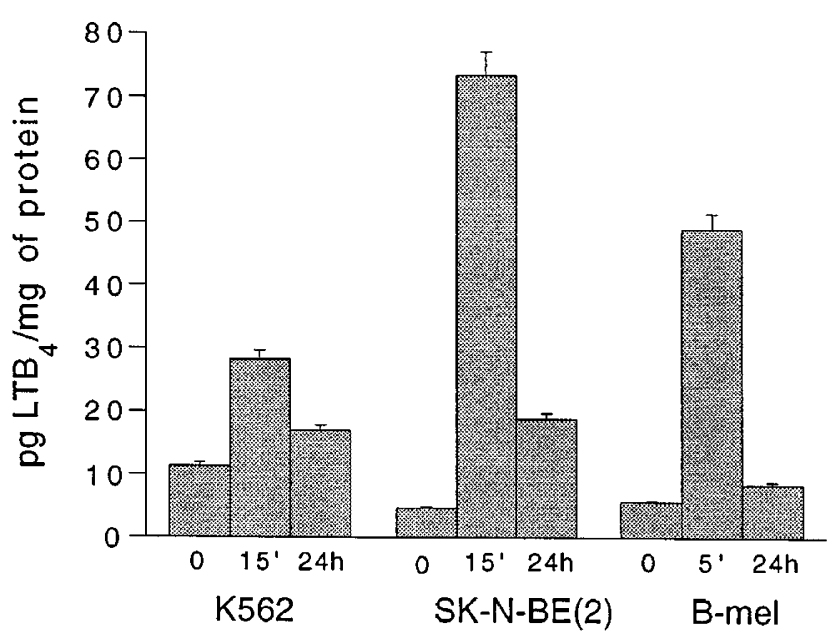

B

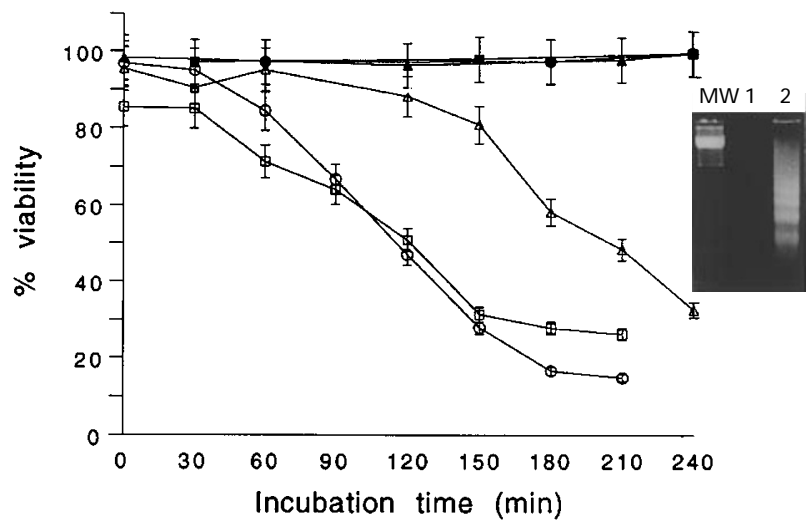

Figure 2 (A) Changes in $\mathrm{LTB}_{4}$ levels in K562, SK-N-BE(2) and B-mel cells. The different cell lines were pulsed with $\mathrm{H}_{2} \mathrm{O}_{2}$ under conditions inducing maximum activation of 5-lipoxygenase and increase of luminescence (asterisks in Figure 1B and C). (B) Cytotoxicity of 5-HETE. The effect of 5HETE on cell viability was evaluated on K562 (empty triangles), SK-N-BE(2) (empty squares) and B-mel (empty circles) cells, compared to untreated controls (full symbols). 5-HETE was used at a final concentration of $5 \mu \mathrm{M}$. Inset. DNA fragmentation of K562 cells, untreated (lane 1) or exposed to $5 \mu \mathrm{M}$ 5 -HETE for $180 \mathrm{~min}$. MW indicates the $123 \mathrm{bp}$ ladder.

1996). Furthermore, leukotriene formation depends on the availability of the substrate, which in turn involves the activity of phospholipases (Yamamoto, 1992).

The possible involvement of 5-lipoxygenase products as effectors of PCD was assessed using a more stable derivative of the enzyme activity, 5-HETE. This metabolite reduced viability (determined by Trypan blue dye exclusion) in all the cell types tested, in a concentration- (not shown) and time-dependent manner (Figure 2B). Cell death induced by 5 -HETE was associated with the DNA ladders typical of apoptosis, both in K562 cells (Figure 2B, inset) and in the other cell types (not shown). Conversely, the general lipoxygenase inhibitor NDGA (Ford-Hutchinson et al, 1994) and the selective 5-lipoxygenase inhibitor caffeic
Table 3 Effect of lipoxygenase inhibitors on $\mathrm{H}_{2} \mathrm{O}_{2}$-induced apoptosis

\begin{tabular}{lccc}
\hline & \multicolumn{3}{c}{$\begin{array}{c}\text { Apoptotic } \\
\text { bodies (\%) }\end{array}$} \\
Sample & No inhibitor & NDGA & Caffeic Acid \\
\hline K562 & $39.7 \pm 3.0$ & $23.5 \pm 2.50$ & $21.83 \pm 2.0$ \\
& $(100 \%)$ & $(59 \%)$ & $(55 \%)$ \\
SK-N-BE (2) & $13.8 \pm 1.2$ & $8.28 \pm 0.80$ & $7.60 \pm 0.77$ \\
& $(100 \%)$ & $(60 \%)$ & $(55 \%)$ \\
B-mel & $14.1 \pm 1.3$ & $8.60 \pm 0.85$ & $7.55 \pm 0.75$ \\
& $(100 \%)$ & $(61 \%)$ & $(53 \%)$ \\
\hline
\end{tabular}

The general lipoxygenase inhibitor NDGA and the selective 5-lipoxygenase inhibitor caffeic acid were added, both at $40 \mu \mathrm{M}$ final concentration, to the culture media of K562, SK-N-BE (2) and B-mel cells. The Table reports the absolute values ( \pm S.D.) and the percentage with respect to the controls (in parentheses). Formation of apoptotic bodies was measured by cytofluorimetry and Hoechst staining. Data are the mean of three independent experiments, each one performed in duplicate, with $p$ values $<0.01$ vs. control (i.e. no inhibitor).

acid (Ford-Hutchinson et al, 1994; Sud'ina et al, 1993; Tang et al, 1996) significantly protected the different tumour cells from $\mathrm{H}_{2} \mathrm{O}_{2}$-induced PCD. Indeed, the addition of either $40 \mu \mathrm{M}$ NDGA or $40 \mu \mathrm{M}$ caffeic acid to the culture medium, together with $\mathrm{H}_{2} \mathrm{O}_{2}$, reduced the number of $\mathrm{H}_{2} \mathrm{O}_{2}$-induced apoptotic bodies by approximately $55-60 \%$ (Table 3 ). Moreover, in the presence of either lipoxygenase inhibitors, cell luminescence decreased to approximately $70 \%$ of the control, i.e. cells pulsed with $\mathrm{H}_{2} \mathrm{O}_{2}$ as shown in Figure 1 (star in panels $\mathrm{B}-\mathrm{C}$ ), whereas superoxide dismutase and catalase activities were not significantly altered.

\section{Discussion}

Treatment with $\mathrm{H}_{2} \mathrm{O}_{2}$ leads to an early significant increase in ultraweak light emission (Figure 1): the $\mathrm{H}_{2} \mathrm{O}_{2}$ pulses generating the largest increase in luminescence for each cell type significantly increased PCD after $24 \mathrm{~h}$ (Table 1). This increase in luminescence suggests an increase in membrane lipid peroxides (Maccarrone et al, 1995a,b; Nakano et al, 1994) which occurs before any morphological and biochemical evidence of PCD. Such lipid peroxidation is paralleled by an increase in 5-lipoxygenase activity; an enzyme that, together with other lipoxygenases, has been shown to induce membrane lipid peroxidation (Kühn et al, 1990; Schnurr et al, 1996). 5-Lipoxygenase activity almost doubled in all cell types only 10-15 min after the $\mathrm{H}_{2} \mathrm{O}_{2}$ pulse, whereas superoxide dismutase activity rapidly decreased and catalase activity transiently increased (Table 1); these changes in 5lipoxygenase and superoxide dismutase activities were most significant $24 \mathrm{~h}$ after treatment with $\mathrm{H}_{2} \mathrm{O}_{2}$, at which time PCD was also maximal, suggesting that the change in activity of both enzymes may be relevant for PCD. Similar results were obtained inducing PCD with RA (Table 2), transforming growth factor $\beta 1$ or cisplatin (not shown), indicating a broader implication of these findings.

First, the involvement of 5-lipoxygenase in apoptosis is supported by the increase in intracellular levels of $\mathrm{LTB}_{4}$ (Figure 2A). The data in Figure 2 indicate that the intracellular concentrations of $\mathrm{LTB}_{4}$ rose to $30 \mathrm{nM}$ (K562), $50 \mathrm{nM}(\mathrm{B}-\mathrm{mel})$ and $70 \mathrm{nM}$ [SK-N-BE(2)], respectively. This 
concentration range was found to evoke a 5-lipoxygenasedependent signal transduction pathway involving protein kinase activation in human cells (Los et al, 1995). More in general, lipoxygenases are key-enzymes for the synthesis of lipid second messengers, which are assuming an increasing importance as PCD-regulators (McGahon et al, 1995). The ability of lipoxygenases to modulate membrane properties (Kühn et al, 1990; Schnurr et al, 1996) might be critical in a process involving the membranes, such as PCD. Along these lines, it has been recently reported that 5 -lipoxygenase and its products are active in the nucleus of mammalian cells (Jakobsson et al, 1995). Second, direct evidence for the relevance of 5-lipoxygenase activity in our systems is provided by the ability of 5 -HETE to induce PCD in the same cell types (Figure 2B). Third, the general lipoxygenase inhibitor NDGA (Ford-Hutchinson et al, 1994) and the more selective 5-lipoxygenase inhibitor caffeic acid (Ford-Hutchinson et al, 1994; Sud'ina et al, 1993; Tang et al, 1996) protected from $\mathrm{H}_{2} \mathrm{O}_{2}$-induced PCD to a similar extent (Table 3 ), suggesting that activation of 5-lipoxygenase, but not other isoenzymes, occurs during apoptosis. NDGA is also a radical scavenger, but its radical scavenging ability is unable to protect human cells against ROS-induced death (O'Donnell et al, 1995; Tang et al, 1996). Therefore, the NDGA protection against $\mathrm{H}_{2} \mathrm{O}_{2}$ induced PCD can be attributed to a true inhibition of lipoxygenase activity. This conclusion is corroborated by the effect of caffeic acid, a specific 5-lipoxygenase inhibitor whose protection against $\mathrm{H}_{2} \mathrm{O}_{2}$-induced PCD (Table 3) correlates with the extent of inhibition of 5-lipoxygenase activity in vitro (Sud'ina et al, 1993). These results extend recent findings on the role of the 12-lipoxygenase pathway in regulating rat cell death (Tang et al, 1996) and indicate that lipoxygenases are indeed involved in the apoptotic programme. This involvement has been recently implied also by Sandstrom et al. (1994), who reported that lipid peroxides induce apoptosis in HIV-infected T cells.

A recent paper describes at morphological level the modulation by LOX-derived eicosanoids during apoptosis of human neutrophils (Hebert et al, 1996). Here, LTB contrary to other LOX-derived eicosanoids including 5HETE, attenuates the spontaneous apoptosis of neutrophils, indicating an involvement in the inflammatory pathway. It is likely that the role of eicosanoids in cell death of inflammatory cells such as neutrophils which are particularly rich in eicosanoids, differs from that in cancer cells. Indeed, $\mathrm{LTB}_{4}$ has been shown to bind and transactivate the transcription factor peroxisome proliferator-activated receptor (PPAR $\alpha$ ), thus directly controlling the expression of anti-inflammatory agents and genes involved in the $\beta$-oxidation pathway such as acyl Co-A oxidase (Devchand et al, 1996). The possibility that such a mechanism is implicated in the absence of inflammatory response in apoptosis, through $\mathrm{LTB}_{4}$, remains to be investigated.

In conclusion, our results show that early activation of the 5-lipoxygenase pathway is associated with PCD, even though the molecular events which allow the execution of the apoptotic programme remain to be fully elucidated.

\section{Materials and Methods}

\section{Materials}

Chemicals were purchased from Sigma (St. Louis, Missouri, USA) or Flow Laboratories Ltd. (Ayrshire, Scotland, UK). The Biotrak $\mathrm{LTB}_{4}$ enzyme immunoassay system was from Amersham (Buckinghamshire, UK).

\section{Cell cultures and treatments}

Erythroleukaemia K562, neuroblastoma SK-N-BE(2) and melanoma B-mel cells were grown as described (Melino et al, 1994). Briefly, cells were grown in monolayer culture in a 1:1 mixture of MEM and Hams F12 media supplemented with $15 \%$ heat-inactivated FBS, sodium bicarbonate $\left(1.2 \mathrm{mg} \mathrm{ml}^{-1}\right)$, HEPES buffer $(15 \mathrm{mM})$, L-glutamine $(2 \mathrm{mM})$ and non-essential amino acids $(1 \% \mathrm{v} / \mathrm{v})$. Cells were grown in $5 \%(\mathrm{v} / \mathrm{v}) \mathrm{CO}_{2}$ humidified atmosphere at $37^{\circ} \mathrm{C}$. Cells were fed every $3-4$ days and were split weekly at a ratio of $1: 3$ to $1: 6$ using trypsin $(0.025 \%)$-EDTA $(0.02 \%)$. Cells were routinely fed $24 \mathrm{~h}$ before harvest for experiments.

RA- or $\mathrm{H}_{2} \mathrm{O}_{2}$-induced apoptosis was provoked as reported (De Laurenzi et al, 1995; Melino et al, 1994). Briefly, cells died within 2-4 $\mathrm{h}$ when exposed to $0.5-2 \mathrm{mM} \mathrm{H}_{2} \mathrm{O}_{2}$ (data not shown); alternatively, cells were treated with either $1 \mathrm{mM}$ RA (5 mM stock solution in $70 \%$ ethanol); $0.07 \%$ ethanol was added to the control cultures. Lipoxygenase inhibitors (NDGA or caffeic acid) were added at the indicated concentrations just before pulsing with $\mathrm{H}_{2} \mathrm{O}_{2}$. Treatments with 5 -HETE ( 1 to $5 \mu \mathrm{M}$ final concentration) were performed by adding hydroperoxide to each cell suspension $\left(2.5 \times 10^{6} \mathrm{cells} / \mathrm{ml} \mathrm{PBS}\right)$. The micromolar concentration range of 5 HETE was chosen because it has been regularly used to study the effect of lipoxygenase products on mammalian cells (O'Donnell et al, 1995; Tang et al, 1996).

In some experiments, dying cells were separated from the whole cell population by gradient centrifugation. Briefly, an equal volume of cell suspension (in PBS) was layered on top of lymphoprep (Nycomed Pharma A.S., Oslo, Norway). After centrifugation at $1800 \mathrm{rpm}$ for $20 \mathrm{~min}$ in a table centrifuge, dying cells were recovered as a pellet, whereas non-dying cells formed an intermediate band between the two fluids at different densities.

\section{Enzyme activity and luminescence measurements}

Cell extracts (Maccarrone et al, 1995) were assayed for the activity of 5-lipoxygenase (EC 1.13.11.34), superoxide dismutase (EC 1.15.1.1) and catalase (EC 1.11.1.6). 5-Lipoxygenase activity was expressed as nmol 5-HPETE (5-hydroperoxyeicosa-6,8,11,14-tetraenoic acid) formed $x$ min $^{-1} x \mathrm{mg}$ protein $^{-1}$ (Van der Donk et al, 1991); superoxide dismutase activity was expressed as units $x \mathrm{mg}$ protein $^{-1}$ (Paoletti and Mocali, 1990) and catalase activity as $\mu \mathrm{mol}$ substrate $\left(\mathrm{H}_{2} \mathrm{O}_{2}\right)$ degraded $x \min ^{-1} x \mathrm{mg}$ protein ${ }^{-1}$ (Aebi, 1984). $\mathrm{LTB}_{4}$ was determined by immunoassay within the linearity range of the calibration curve (pure $\mathrm{LTB}_{4} 0-10 \mathrm{pg} /$ well).

Luminescence (Maccarrone et al, 1995), counts $x \mathrm{~s}^{-1} x \mathrm{mg}$ protein $^{-1}$ (cps $x \mathrm{mgP}^{-1}$ ), was expressed as the percentage of the control values, i.e. 320,126 and $84 \mathrm{cps} x \mathrm{mgP}^{-1}$, for K562, SK-N$\mathrm{BE}(2)$ and B-mel cells, respectively. Ultraweak luminescence was measured by single photon counting in a Lumi-A luminometer (SEAS, Milan, Italy) using $10^{6}$ cells/ml PBS suspended in $1 \mathrm{ml}$ cuvettes. Cellular luminescence is proportional to the peroxidation of membrane lipids (Maccarrone et al 1995b; Nakano et al, 1994). 


\section{Evaluation of cell death}

After incubation for $24 \mathrm{~h}$ in culture medium, floating and enzymaticallydetached cells were collected together by centrifugation at $800 \times g$ for $5 \mathrm{~min}$. Apoptosis was estimated in all experiments using standard procedures, such as cytofluorimetric analysis (see also Piacentini et al, 1993; Melino et al, 1994) and Hoechst staining (Hoechst 33258 , $0.1 \mu \mathrm{g} / \mathrm{ml} \mathrm{PBS}$, at $37^{\circ} \mathrm{C}$ for $1 \mathrm{~h}$, washed, air dried and mounted). Tunel (TdT-mediated dUTP-biotin nick end labeling) (see also Melino et al, 1994) and DNA ladder (Martin et al, 1995) were also used to assess DNA fragmentation.

Briefly, DNA fragmentation of death cells was evaluated by flow cytometry by staining with propidium iodide $(50 \mu \mathrm{g} / \mathrm{ml}$; pre-treated also with RNase to reduce noise) on a FACScan flow cytometer (BectonDikinson, CA, USA). Cells were fixed $1: 1$ in PBS using methanol: acetone $(4: 1 \mathrm{v} / \mathrm{v})$ solution at $-20^{\circ} \mathrm{C}$ and stored at $+4^{\circ} \mathrm{C}$. Cells were excited at $488 \mathrm{~nm}$ using a $15 \mathrm{~mW}$ Argon laser, and the fluorescence was monitored at $570 \mathrm{~nm}$. Events were triggered by the FSC signal and gated for FSC-H/FSC-A/SSC to avoid aggregates. Ten thousand events were evaluated using the Lysis II Programme (ibid).

Data reported in this paper are the mean of triplicate experiments, with S.D. values as indicated in the text. Statistical analysis was performed by the Student's $t$-test.

\section{Acknowledgements}

This work was supported by Istituto Superiore di Sanità (VIII AIDS Project 1995 to AFA), Centro Nazionale delle Ricerche (CNR-ACRO to GM), Ministero della Pubblica Istruzione and Sanità and AIRC (to M. Piacentini). We gratefully acknowledge financial support from Telethon (1996-E413 to GM) and Ass. Neuroblastoma, IGG Genova (to GM).

\section{References}

Abate C, Patel L, Rauscher III FJ and Curran T (1990) Redox regulation of Fos and Jun DNA-binding activity in vitro. Science 249: 1157-1161

Aebi H (1984) Catalase in vitro. Methods Enzymol 105: 121-126

Baker AF, BriehI MM, Dorr Rand Powis G (1996) Decreased antioxidant defense and increased oxidant stress during dexamethasone-induced apoptosis: bcl-2 selectively prevents the loss of catalase activity. Cell Death Differ 3: 87-93

Bissonnette RP, Brunner T, Lazarchik SB, Yoo NJ, Boehm MF, Green DR and Heyman RA (1995) 9-cis Retinoic acid inhibition of activation-induced apoptosis is mediated via regulation of Fas ligand and requires retinoic acid receptor and retinoid X receptor activation. Mol Cell Biol 15: 5576-5585

Boise LH, Gonzalez-Garcia M, Postema CE, Ding L, Lindsten T, Turka LA, Mao X, Nunez $G$ and Thompson CB (1993) Bcl-x, a bcl-2-related gene that functions as a dominant regulator of apoptotic cell death. Cell 74: 597-608

Briehl MM, Cotgreave IA and Powis G (1995) Downregulation of the antioxidant defense during gluococorticoid-mediated apoptosis. Cell Death Differ 2: 41-46

Chittenden T, Harrington EA, O'Connor R, Flemington C, Lutz RJ, Evan GI and Guild BC (1995) Induction of apoptosis by the Bcl-2 homologue Bak. Nature 374: 733 736

De Laurenzi V, Melino G, Savini I, Annicchiarico-Petruzzelli M, Finazzi Agrò A and Avigliano $L$ (1995) Cell death by oxidative stress and ascorbic acid regeneration in human neuroectodermal cell lines. Eur J Cancer 31A: 463-466

Devchand PR, Keller H, Peters JM, Vazquez M, Gonzalez, Whali W (1996) The PPAR $\alpha$-leukotriene $B_{4}$ pathway to inflammation control. Nature 384: 39-43

Farrow SN, White JHM, Martinou I, Raven T, Pun KT, Grinham CJ, Martinou JC and Brown R (1995) Cloning of a bcl-2 homologue by interaction with adenovirus E1B 19K. Nature 374: 731-733

Ford-Hutchinson AW, Gresser M and Young RN (1994) 5-Lipoxygenase. Annu Rev Biochem 63: 383-417

Hale AJ, Smith CA, Sutherland LC, Stoneman VEA, Longthorne VL, Culhane AC and Williams GT (1996) Apoptosis: molecular regulation of cell death. Eur J Biochem 236: $1-26$
Hebert MJ, Takano T, Holthofer H, Bredy HR. (1996) Sequencial morphological events during apoptosis of human neutrophils. Modulation by lipoxygenasederived eicosanoids. J Immunol 157(7): 3105-3115

Hockenbery DM, Oltval ZN, Yin X-M, Milliman CL and Korsmeyer SJ (1993) Bcl2 functions in an antioxidant pathway to prevent apoptosis. Cell 75: $241-$ 251

Jacobson MD and Raff MC (1995) Programmed cell death and Bcl-2 protection in very low oxygen. Nature 374: 814-816

Jakobsson P-J, Shaskin P, Larsson P, Feltenmark S, Odlander B, AguilarSantelises M, Jondal P and Claesson H-E (1995) Studies on the regulation and localization of 5-lipoxygenase in human B-lymphocytes. Eur J Biochem 232: $37-46$

Kane DJ, Sarafian TA, Anton R, Hahan H, Butler Gralla EB, Valentine JS, Ord T and Bredesen DE (1993) Bcl-2 inhibition of neuronal death: decreased generation of reactive oxygen species. Science 262: $1274-1277$

KleferMC, BrauerMJ, Powers VC, Wu JJ, Umansky SR, Tomei LD and Barr PJ(1995) Modulation of apoptosis by the widely distributed Bcl-2 homologue Bak. Nature 374: $736-739$

Kühn H, Belkner J, Wiesner R and Brash AR (1990) Oxygenation of biological membranes by the pure reticulocyte lipoxygenase. J Biol Chem 265: $18351-$ 18361

Los M, Schenk H, Hexel K, Baeuerle PA, Droge W and Schulze-Osthoff K (1995) IL-2 gene expression and $\mathrm{NF}-\mathrm{kB}$ activation through $\mathrm{CD} 28$ requires reactive oxygen production by 5-lipoxygenase. EMBO J 14: 3731 - 3740

Maccarrone M, Bladergroen MR, Rosato N and Finazzi Agrò A (1995a) Role of lipid peroxidation in electroporation-induced cell permeability. Biochem Biophys Res Commun 209: 417-425

Maccarrone M, Rosato N and Finazzi Agrò A (1995b) Electroporation enhances cell membrane peroxidation and luminescence. Biochem Biophys Res Commun 206: $238-245$

Martin SJ, Takayama S, McGahon AJ, Miyashita T, Corbeil J, Kolesnick RN, Reed JC and Green DR (1995) Inhibition of ceramide-induced apoptosis by Bcl-2. Cell Death Differ 2: 253-257

McGahon AJ, Nishioka WK, Martin SJ, Mahboubi A, Cotter TG and Green DR (1995) Regualtion of the Fas apoptotic cell death pathway by Abl. J Biol Chem 270: 22625-22631

Melino G, Annicchiarico-Petruzzelli M, Piredda L, Candi E, Gentile V, Davies PJA and Piacentini M (1994) Tissue-transglutaminase and apoptosis: sense and antisense transfection studies in human neuroblastoma cells. Mol Cell Biol 14: $6584-6596$

Meyer M, Schreck R and Baeuerle PA (1993) $\mathrm{H}_{2} \mathrm{O}_{2}$ and antioxidants have opposite effects on activation of NF-kB and AP-1 in intact cells: AP-1 as secondary antioxidant-responsive factor. EMBO J 12: 2005-2015

Nakano M, Ito T, Arimoto T, Ushiijima Y and Kamiya K (1994) A simple luminescence method for detecting lipid peroxidation and antioxidant activity in vitro. Biochem Biophys Res Commun 202: 940-946

O'Donnell VB, Spycher S and Azzi A (1995) Involvement of oxidants and oxidantgenerating enzyme(s) in tumour-necrosis-factor- $\alpha$-mediated apoptosis: role for lipoxygenase pathway but not mitochondrial respiratory chain. Biochem J 310: $133-141$

Oltvai ZN, Milliman CL and Korsmeyer SJ (1993) Bcl-2 heterodimerizes in vivo with a concerved homolog, Bax, that accelerates programmed cell death. Cell $74:$ $609-619$

Paoletti F and Mocali A (1990) Determination of superoxide dismutase acivity by a purely chemical system based on NAD(P)H oxidation. Methods Enzymol 186: $209-220$

Piacentini M, Annicchiarico-Petruzzelli M, Oliverio S, Piredda L, Biedler JL and Melino G (1992) Phenotype-specific tissue transglutaminase regulation in human neuroblastoma cells in response to retinoic acid: correlation with cell death by apoptosis. Int J Cancer 52: 271-279

Piacentini M, Fesus L and Melino G (1993) Multiple cell cycle access to the apoptotic death programme in human neuroblastoma cells. FEBS Lett 320: 150-154

Raff M (1992) Social control on cell survival and cell death. Nature 356: 397-400

Sandstrom PA, Tebbey PW, Van Cleave S and Buttke TM (1994) Lipid hydroperoxides induce apoptosis in T cells displaying a HIV-associated glutathione peroxidase deficiency. J Biol Chem 269: 798-801

Schnurr K, Hellwing M, Seidemann B, JungblutP, Kühn H, Rapoport SM and Schewe $T$ (1996) Oxygenation of biomembranes by mammalian lipoxygenases: the role of ubiquinone. Free Rad Biol Med 20: 11-21 
Shimizu S, Eguchi Y, Kosaka H, Kamiike W, Matsuda H and Tsujimoto Y (1995) Prevention of hypoxia-induced cell death by Bcl-2 and Bcl-xL. Nature 374:811 813

Steinkühler C, Mavelli I, Melino G, Piacentini M, Rossi L, Weser Uand Rotilio G (1988) Antioxygenic enzyme activities in differentiating human neuroblastoma cells. Ann NY Acad Sci 551: 137-140

Steinman HM (1995) The Bcl-2 oncoprotein functions as a pro-oxidant. J Biol Chem 270: $3487-3490$

Stoler DL, Anderson GR, Russo CA, Spina AM and Beerman TA (1992) Anoxiainducible endonuclease activity as a potential basis of the genomic instability of cancer cells. Cancer Res 52: 4372-4378

Sud'ina GF, Mirzoeva OK, Pushkareva MA, Korshunova GA, Sumbatyan NV and Varfolomeev SD (1993) Caffeic acid phenethyl ester as a lipoxygenase inhibitor with antioxidant properties. FEBS Lett 329: 21-24

Takayama S, Sato T, Krajewski S, Kochel K, Irie S, Millan JA and Reed JC (1995) Cloning and functional analysis of BAG-1: a novel $\mathrm{Bcl}-2$-binding protein with anticell death activity. Cell 80: $279-284$
Tang DG, Chen YQ and Honn KV (1996) Arachidonate lipoxygenases as essentia regulators of cell survival and apoptosis. Proc Natl Acad SciUSA 93:5241 - 5246 Torres-Roca JF, Lecoeur H, Amatore C and Gougeon ML (1995) The early intracellular production of reactive oxygen intermediate mediates apoptosis in dexamethasone-treated thymocytes. Cell Death Differ 2: 309-319

Van der Donk EMM, Verhagen J, Veldink GA and Vliegenthart JFG (1991) 12 Lipoxygenase from rat basophilic leukemia cells: separation from 5 lipoxygenase and temperature-dependent inactivation by hydroperoxy fatty acid. Biochim Biophys Acta 1081: 135-140

Wolfe JT, Ross D and Cohen GM (1994) A role for metals and free radicals in the induction of apoptosis in thymocytes. FEBS Lett 352: 58-62

Yamamoto S (1992) Mammalian lipoxygenases: molecular structures and functions. Biochim Biophys Acta 1128: 117-131

Yang E, Zha J, Jockel J, Boise LH, Thompson GB and Korsmeyer SJ (1995) Bad, a heterodimeric partner for $\mathrm{Bcl}-\mathrm{XI}$ and $\mathrm{Bcl}-2$, displaces Bax and promotes cell death. Cell 80: 285-291 